\title{
THE IMPROVEMENT OF THE INVESTMENT ATTRACTIVENESS OF INDUSTRIAL ENTERPRISES IN THE CONVENTION OF THE COVID-19 PANDEMIC
}

\author{
Olena Ocheredco ${ }^{1}$ \\ ${ }^{I}$ Azov Maritime Institute of National University «Odessa Maritime Academy», Mariupol, Ukraine \\ e-mail: ocheredcoelena@gmail.com
}

Received: 13 July 2020; Accepted: 13 August 2020; Published: 01 September 2020

\begin{abstract}
In this article we consider the directions of increasing the investment attractiveness of the holding's industrial enterprises in the COVID-19 pandemic conditions. In today's challenging industrial environment, most companies need to raise additional funds to pursue an active anti-crisis and investment policy. At the same time, while determining the potential object of investment resources, an investor focuses on the investment attractiveness of the enterprise and the region as a whole. The main tendencies for increasing the efficiency of the investment activity at the state and regional levels are developed. The basic methods of regulation of investment processes, the priority directions of use of the state and non-state sources of financing are determined. The main factors hindering the processes of the investment activity are summarized. The priority tasks for the reform of administrative mechanisms at the enterprise level are identified. Therefore, there is a need to consider ways to increase the investment attractiveness of enterprises in modern conditions.
\end{abstract}

Key words: increase, investment attractiveness, industrial enterprises, investments, COVID-19 pandemic.

JEL classification: H10; H50; E22, D24

How to Cite:

Ocheredco, O. 2020. The improvement of the investment attractiveness of industrial enterprises in the convention of the COVID-19 pandemic. Access journal, ACCESS Press, 1(2): 131-145, https://doi.org/10.46656/access.2020.1.2(5)

\section{INTRODUCTION}

At the current stage of development of Ukraine's economy, profound changes are taking place due to the general processes of the crisis associated with the COVID-19 pandemic and the economic recession, which requires effective steps to overcome it. Experience shows that more and more industrial enterprises are searching for urgent assistance from the authorities and science that must justify mechanisms to prevent bankruptcy of enterprises that will ensure the proper management of crisis situations and processes. It is impossible to get out of the financial crisis without a scientific substantiation of the mechanisms of anti-crisis management of the holding's enterprises. Therefore, the study is undoubtedly relevant today.

In recent years, the dynamics of investment processes began to decline. Therefore, our government should analyze the indicators in more detail and start developing real measures that will lead to increase of investment attractiveness of industrial enterprises in Ukraine. At the same time, Ukrainian holding companies should intensify all their opportunities to attract investment and improve the investment activities of enterprises. 
In the current conditions, the investment attractiveness of enterprises requires the improvement and enhancement the legal, socio-economic, financial, and socio-political components; this way, it can lead to growth of investment resources and contribution to the overall socio-economic development of Ukraine.

Attracting investment is very important for the activities of enterprises and it requires management of such enterprises to constantly improve anti-crisis activities and increase the level of investment benefits compared to other enterprises.

\section{Latest research and objectives}

The issue of increasing the investment attractiveness of industrial enterprises of Ukraine in the crisis period needs further study and generalization. To effectively attract investment, it is necessary to form effective investment attractiveness at industrial enterprises. Therefore, the conditions should be created, when the utilizing of such investments will provide the maximum economic and social effect from their implementation in compliance with the established level of investment risk.

This is especially important for the category of investors that do not have clear investment interests and form their investment strategy based on an assessment of the investment attractiveness of the enterprise.

Many works are devoted to the causes of the crisis in Ukraine, in particular: Babil (2011), Gritsenko (2011), Yurchuk (2012), Sushchenko (2016), Akhmetshin et al. (2019), Madaminjonov (2020), Matyushenko et al (2020), Ramazanov\&Petrova (2020), Labunska et al (2017), Sushchenko et al (2019), Zagorodnya et al. (2020). The developments of effective management of the enterprise are presented in such signtific research as: Petrovich (2008), Gura (2018), Khidirov (2020), Zhernov et al (2020), Tepavicharova et al. (2020).

The purpose of the article is to consider and introduce the measures to improve the investment attractiveness of industrial enterprises in the conditions of the COVID-19 pandemic.

\section{Results}

According to the International Monetary Fund, the world economy is expected to fall by 3 per cent. At the same time, Ukraine has traditionally been more vulnerable to economic shocks: GDP may fall by $4-8 \%$ in 2020 compared to 2019. The expected decline in Ukraine's economy is a consequence of global shocks: an unfavourable situation in important commodity markets for Ukraine, the closure of commodity markets for Ukrainian exporters, a change in global production chains.

According to the forecasts of the National Bank of Ukraine, Ukraine in 2020 may face a decline in exports to $-10 \%$, imports to $-14.5 \%$, expanding the budget deficit to $8 \%$ and growth of the gross domestic product and unemployment to $9.5 \%$. During the crisis, industrial enterprises face a liquidity shortage. Measures aimed at saving funds by reducing tax and administrative pressures, reducing the cost of raw materials, transportation and energy will minimize the decline in production, employment and exports in the industry. 
Effective tools to promote exports and facilitate access to key raw materials for businesses should be identified. At the same time, during the deteriorating situation in foreign markets, it is important to stimulate industrial production by increasing domestic demand through public procurement and by protecting local manufactures. The crisis should be used to prepare the ground for growth by saturating the sector with equipment for the transition to higher value-added production, designing and building infrastructure for industrial parks to attract investment, and promote environmental modernization.

The high export orientation of the industry creates both risks and opportunities. Industry provides 58\% of merchandise exports, and, accordingly, significant foreign exchange income for the Ukrainian economy. The domestic market has a low capacity: $51 \%$ of industrial sales are made though foreign markets; this makes the industry sensitive to changes in world conditions and protective measures of other countries. The crisis surrounding the COVID-19 pandemic will exacerbate existing problems in the industry.

In particular, the metallurgical industry before the pandemic experienced a decline due to deteriorating world conditions. For example, steel prices have fallen by about 30\% since 2018. Mechanical engineering was in the process of recovery after the loss of traditional markets, capacity in the occupied territories and the economic crisis, from 2012 to 2015 . The sales fell threefold, which was very slow due to outdated funds and insufficient capital investment for modernization. Declining demand in domestic and global markets, the rupture of production chains due to the pandemic and the economic crisis will exacerbate existing problems.

Exports of metal products provide $26 \%$ of Ukrainian exports of goods and are one of the main sources of foreign exchange earnings. The mining and metallurgical complex import equipment and raw materials that are not produced or insufficiently produced in Ukraine. Mechanical engineering industry mainly exports semifinished products, around 67\%, including spare parts for cars, air and rail transport, communication equipment. The largest segments of finished products for export are household appliances, ships, engines, and generators. In comparison, about $70 \%$ of finished machine-building products are imported to Ukraine, such as vehicles, agricultural machinery, computers, and household appliances.

At the same time, domestic engineering depends on imports of the intermediate consumption of spare parts and components, metallurgical products of approximately 53\% in (Cabinet of Ministers of Ukraine, 2020).

The mining and metallurgical complex sells only $15 \%$ of the products on the domestic market and is a supplier for domestic orders in the quantity of $68 \%$ for construction, $23 \%$ for mechanical engineering; and a consumer for mechanical engineering - $6 \%$ of domestic orders, transport - about $40 \%$ of all transported goods by rail and water, energy - $10 \%$ of electricity.

The investment attractiveness of a holding company is a set of qualitative and quantitative indicators that comprehensively determine the ability to increase invested capital, and as an integral indicator formed under the influence of influencing factors, determines the investor's willingness or refusal to invest in such an instrument as an industrial enterprise. To determine the method of assessing the investment attractiveness of 
the enterprise it is necessary to take into account all possible fields of factors influencing its investment attractiveness (Fig. 1).

According to Endovitsky (2010, p. 374), factors that affect the investment attractiveness of the enterprise can be divided into two groups: external factors in relation to the enterprise and internal ones. External factors are factors that do not depend on the results of economic activity of the enterprise. These include the investment attractiveness of the territory, and the investment attractiveness of the industry. Internal factors include factors that depend directly on the result of economic activity of the enterprise.

Therefore, internal factors are the main lever of influence on the investment attractiveness of the enterprise. These factors include the financial condition of the enterprise, the organizational structure of enterprise management, the degree of innovation of the company's products, the stability of cash flow generation, the level of diversification of the company's products, and more. Blank (2011), Vorobyov, Vorobyova (2004) in their works distinguish five indicators: the importance of the industry, the characteristics of product consumption, the level of government intervention, social role of the industry, and financial conditions of the industry.

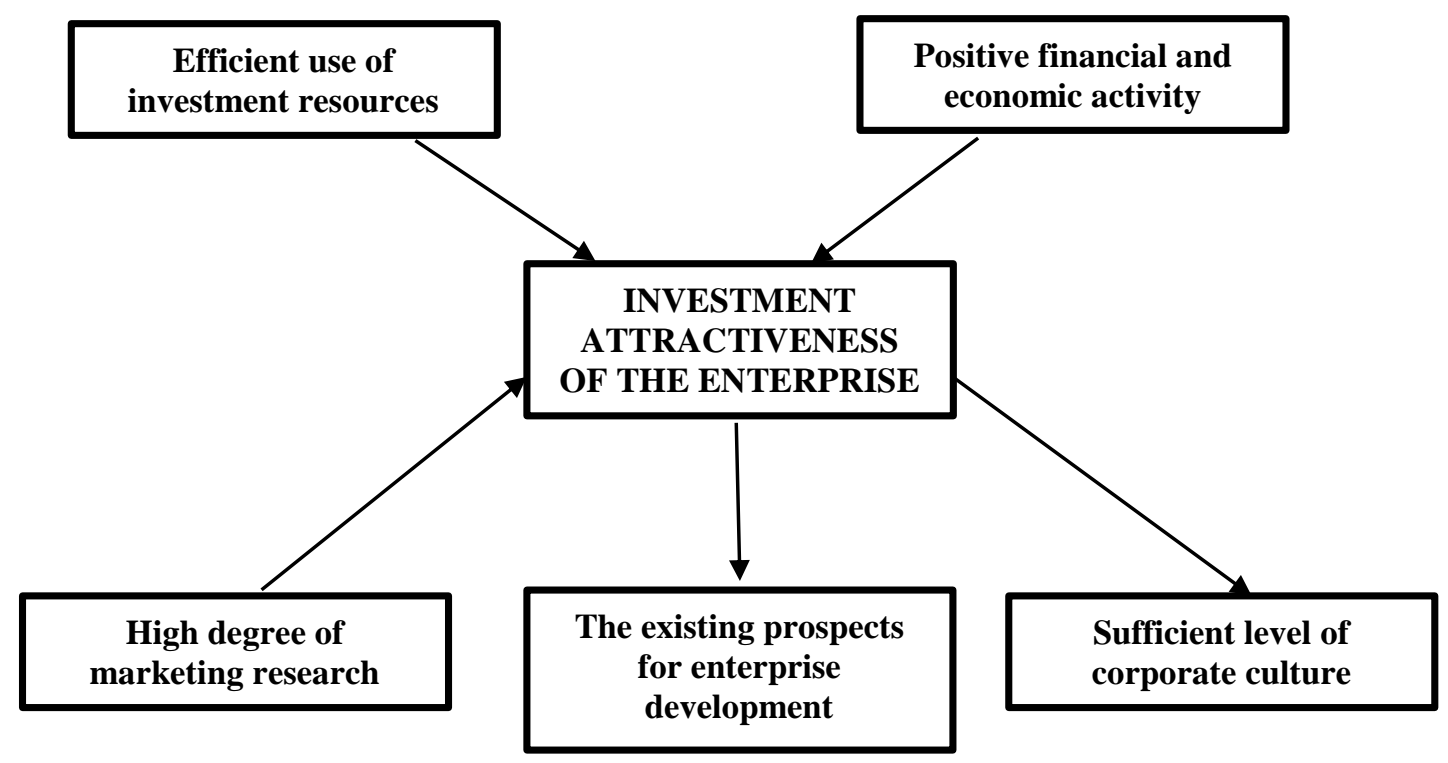

Fig. 1. The main components of the investment attractiveness of the enterprise Source: prepared by the author

All factors were grouped into two groups: factors of indirect and direct influence of the enterprise on investment attractiveness. The first group includes factors that are not subject to the influence of an individual enterprise, they can be adjusted only at the state level. The second group includes factors that the company can influence in order to change their performance, characteristics, and so on.

Factors of direct influence are the most important ones for an enterprise. Because of these factors, the enterprise can independently influence investment attractiveness. Among the most important factors of direct 
influence are such factors as human resources, duration of the investment program, the state of property and financial resources, and the amount of expenses. For the industrial enterprise of the holding, internal factors or factors of direct influence are more important, as because of them, the enterprise is capable of independently influencing its investment attractiveness.

Among the internal factors, the most important are human resources, duration of the investment program, the state of property and financial resources, and the amount of expenses. In fig. Figure 2 shows the most important factors influencing the investment attractiveness of the holding's industrial enterprise.

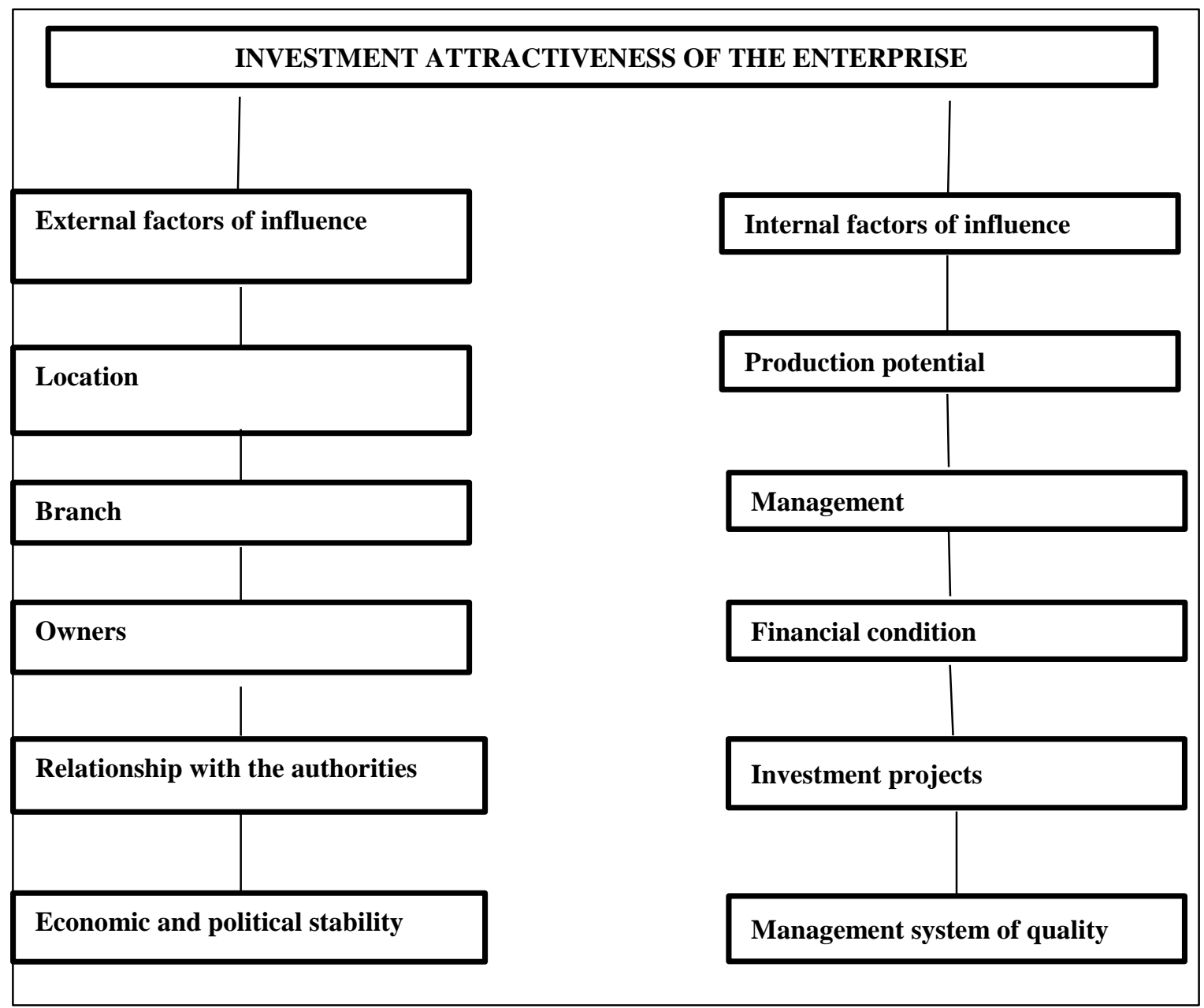

Fig. 2. Factors effecting the investment attractiveness of the holding's industrial enterprise Source: prepared by the author

It should be emphasized that the investor when choosing an investment object pays most attention to the state of property, financial resources, the cost of the enterprise, which is determined by the degree of depreciation of fixed assets, their ability to produce products at a high level, liquidity, solvency, financial performance stability, indicators of business activity, the state of non-current and current assets, their renewal 
and disposal. The amount of costs of the enterprise includes all the costs of the enterprise associated with its operating activities (Baklanova, Petrova, Koval, (2020).

After defining the factors that influence the formation of investment attractiveness, we can clarify the more vulnerable aspects of the enterprise and, as a consequence, to conduct a more objective and complete assessment.

Based on the analysis of the existing literature, the proposed quantitative and qualitative factors that affect the investment attractiveness of an industrial enterprise are listed in Table 1.

Table 1. Factors influencing the investment attractiveness of an industrial enterprise

\begin{tabular}{|l|l|l|}
\hline $\begin{array}{l}\text { External environment and market position } \\
\text { of the enterprise }\end{array}$ & Financial condition of the enterprise & Enterprise management \\
\hline External market environment & Return on equity in terms of net income & Financial transparency and disclosure \\
\hline The geography of the exported products & Profitability of sales at net profit & Corporative management \\
\hline $\begin{array}{l}\text { Investment climate of the region, in which } \\
\text { the company is located }\end{array}$ & Asset turnover ratio & $\begin{array}{l}\text { The percentage of shares in free } \\
\text { circulation on the secondary securities } \\
\text { market }\end{array}$ \\
\hline The degree of competition in the market & The ratio of borrowed and own funds & $\begin{array}{l}\text { Observance of the rights of small } \\
\text { shareholders to manage the enterprise }\end{array}$ \\
\hline Ecological environment & Current ratio & $\begin{array}{l}\text { Degree of protection of shareholders' } \\
\text { rights }\end{array}$ \\
\hline $\begin{array}{l}\text { Investment attractiveness of the } \\
\text { company's industry }\end{array}$ & Financial condition of the enterprise & $\begin{array}{l}\text { The share of state property in the } \\
\text { authorized capital of the company }\end{array}$ \\
\hline $\begin{array}{l}\text { Stage of the life cycle of the main type of } \\
\text { product }\end{array}$ & Coefficient of ownership (autonomy) & $\begin{array}{l}\text { The amount of remuneration to members } \\
\text { of the board of directors }\end{array}$ \\
\hline
\end{tabular}

The conducted review showed the importance and necessity of separation and systematization of factors that comprehensively characterize the investment attractiveness of industrial enterprises (Petrova et al., 2020). The study and monitoring of such factors form the basis for effective diagnosis of the level and index of investment attractiveness of a particular industrial enterprise and Ukraine as a whole for a real investor. Thus, all the considered factors, which comprehensively characterize the investment attractiveness of the industrial enterprise of the holding, closely interact and interact with each other.

Therefore, in the current difficult conditions of industrial functioning, when the functioning of enterprises is constantly affected by the crisis, it is necessary to consider the investment attractiveness of economic activity in the current conditions. The crises of recent decades indicate the inability of national and international institutions for a long time to ensure stability and balance in financial markets. Modern processes have led to a number of unfavourable factors for the development of national financial systems, so the crisis associated with COVID-19 for industrial enterprises in Ukraine was a very serious test.

Ukraine's industrial enterprises find it difficult to survive the crisis, and it is important for those who survived to develop effective financial management aimed at overcoming future post-crisis consequences. All countries of the world have suffered from this, but some have managed to get out of it at lower cost. Practical measures to combat the crisis were taken, such as lowering the discount rate on loans, government guarantees for interbank loans, nationalization of investment institutions. creation of special credit funds, providing tax holidays, etc. 
The capacity of the government in a crisis makes it impossible to fully implement the envisaged methods and measures. Many of the approved anti-crisis policy programs remain only strategic intentions, the implementation of which should take place through the adoption of regulations in the Verkhovna Rada. The economy of our country was not ready to respond quickly to the crisis. The negative effects of the crisis on Ukraine's economy can be considered in the following aspects: slowdown in the development of the financial services market of Ukraine; reduction of aggregate demand of the population due to negative expectations, which, in turn, leads to a decrease in GDP growth; weakening the business activity of society; reduction of production by credit-dependent enterprises; the desire of some Ukrainian politicians to "transfer" the problems of the financial market to the industry and the population of Ukraine in general.

The study of the practice of developing anti-crisis measures showed that today companies prefer to develop a protective strategy, which is characterized by curtailment, and offensive strategies of enterprises are in the waiting stage, characterized by in-depth study of cost reduction and search for innovative approaches to production and sales technologies. principles of anticipation of demand.

Only by producing products that are ahead of modern demand, the company can stay working and even develop in a crisis. It is clear that such products are new and more efficient in consumption. Unfortunately, the financial crisis has led to an increase in the number of financially insolvent enterprises in each sector of Ukraine's economy, due, firstly, to objective macroeconomic instability, and secondly, a number of subjective factors, among which the inability of management comes first. to carry out effective anti-crisis management of the enterprise, timely identify problems and take the necessary measures (Budnikova, 2014).

Today, industrial enterprises face both external and internal factors of the crisis. The influence of external factors is mainly general economic, objective, strategic in nature and is further enhanced by the influence of a number of market and political factors. Internal factors that affect the results of the enterprise are closely related to its operating, investing and financing activities. Based on statistical data, it should be noted that the current state of Ukraine's structures is characterized by first, the rapid laundering of working capital due to the impossibility of obtaining short-term loans to optimize current activities, as well as the freezing of development programs; second, massive breaches of payment obligations; third, the reduction of production due to reduced demand in foreign and domestic markets; fourth, mass layoffs or vacations at the expense of employees, reduction of work shifts from 2-3 to one, the transition to part-time work (Usherenko, 2010). According to experts, the most vulnerable to the crisis were companies focused on export (metallurgy, transport, and agricultural engineering), as well as on the consumer sector (car production). Under such conditions, the management of enterprises must ensure the development of anti-crisis measures for at least a year. Such development should be comprehensive, aimed at forming an optimal portfolio of anti-crisis measures, the implementation of which will help get the company out of crisis, restore its solvency and liquidity. 
In Ukraine, the factors influencing the investment process are in such a state that they cannot contribute to the development of this process. However, the experience of many countries shows that the way out of the crisis is impossible without attracting new investments.

Thus, the intensification of investment activity is also hampered by the political situation, while a way out of the crisis without a significant increase of investment is impossible. However, with the monetary reform in Ukraine, a factor of economic stabilization has emerged. However, it should be consolidated and strengthened by real, not declarative, reforms. We are talking about overcoming inflation. High inflation rates make the accumulation of financial resources aimed at long-term projects completely inefficient. Reducing inflation makes it possible to normalize the financial condition of enterprises, to stimulate increased production.

The management of investment activities is influenced by a variety of factors that have external and internal nature and direct or indirect influence on an individual enterprise. External factors that effect the investment activities of the enterprise can be divided into four main groups: international factors, industry factors, factors related to the state management of investment activities, market factors. Each of these groups of factors indirectly affects the process of investment management, however, in the absence of prompt response to them by management, these factors can lead to negative consequences.

Internal factors influencing the management of investment activities are determined by the activities of the industrial enterprise as a whole, the level of employees skills, the ability of management and employees to respond to changes in the external environment, the level of business activity and reputation of the enterprise, the development of the sales and marketing system, the process of organizing production, and the availability of the necessary resources.

At the present stage, the investment activity of enterprises should be focused not only on meeting current investment needs, but also on prediction of the directions and forms of this activity in the future. This necessitates the formation of the management system for investment attractiveness, taking into account development trends, and the system of opportunities and threats, which can be determined by conducting SWOT-analysis, taking into account the investment benefits and threats of the enterprise.

Among the investment advantages, one of the priorities for enterprises in general, and especially for industrial enterprises of the holding, is to attract investment in order to introduce innovations, which are necessary for the intensive development of the country's economy. Innovation, by increasing the efficiency of the economy, expands sources of investment. One more fact that proofs the priority of investment in innovation is the problem of rational use of available financial resources. The problem is the formation of such an investment structure that is characterized by progressive changes. Areas of investment are characterized by reproductive and technological structures. The reproducible structure of investment in fixed capital characterizes the distribution of investment in construction and technical re-equipment, expansion and reconstruction of manufacture. The share of obsolete equipment in some industries is 60-70 per cent. 
Ukrainian industrial enterprises do not ensure the proper rate of its renewal. The industry is dominated by outdated technologies. This leads to unjustifiably high consumption of energy in the Ukrainian industry. In Ukraine, it is 4-5 times higher than in European countries. The equipment of mechanical engineering is updated extremely slowly as well, while it is designed to be a powerful engine of innovation processes in all sectors of the national economy (Babil, 2011).

The Ukrainian economy needs capital for the construction of new, and reconstruction and modernization of existing enterprises. But, unfortunately, foreign analysts see our country as a region with almost 100 per cent risk for investment.

In order to improve the investment attractiveness of the country and enterprises, it is necessary to provide the required conditions for business operations and to develop a system of guarantees and exemptions for foreign investors. The priorities of economic development are the introduction of educational, scientific and technical activities, the implementation of measures to concentrate investment resources on the implementation of investment projects.

Analysis of national legislation in the field of investment regulation is unstable, the regulatory framework is constantly changing, because in the process of its formation, some regulations are adopted, others are repealed, or their provisions are reflected in other regulations.

The general state of the economy is significantly influenced by tax legislation system that has a lot of shortcomings in Ukraine. Therefore, in the future the government should provide for a reduction of tax pressure on manufacture, differentiation of tax rates depending on the priority of manufacture areas, the application of tax exemptions for profits used for the development of production.

Analyzing the scientists' views, we can see that the directions of improving the investment attractiveness of industrial enterprises in a market economy country should be based on the following principles:

- the objective need to recognize long- and medium-term cycles of investment activity;

- interaction of local, branch, regional and national economic cycles of investment activity;

- formation of market levers in the investment sphere simultaneously with similar processes in other sectors of the economy;

- logic and integrity of the investment cycle;

- succession in the implementation of specific measures;

- priority of directing funds for the implementation of the investment process (Petrovich, 2008).

All over the world, capital financing is largely done in the form of credit resources. However, due to the imperfection of our banking system and the general state of the economy, investment loans are now almost non-existent. The banking system of our country does not have the ability to sufficiently lend to national manufactures. One of the sources of domestic financing is the strengthening the control over foreign economic transactions. This will help to ensure the return of export earnings. 
Foreign loans for our economy have reached a significant size, but are used mainly for current consumption. Ukraine often receives so-called "tied" loans, which can be used only to purchase goods from the creditor countries.

Thus, investors, especially foreign ones, search for the information about the conditions that influence the formation of investment attractiveness of the enterprise. The availability of complete information about the industry, region and, especially, business conditions significantly effect the attractiveness of an enterprise.

The experience of working with Ukrainian and foreign investors shows that a strategic investor will always be interested in an attractive company in an investment-attractive industry and an attractive region.

The main directions of improving Ukraine's investment attractiveness for foreign investors should be:

- consistent reduction of pressure on investors and the revocation of diversified sources of investment, uneven distribution between regions;

- creation of effective mechanisms for investment management;

- restructuring the economy, priority investments in the industries that require investments the most;

- increase motivation of business entities in long-term investments, as well as of the population in investing in economic development, rather than consumption;

- stimulating reinvestment;

- improvement of investment legislation and ensuring its stability;

- providing guarantees to investors;

- correspondence between the inflow and outflow of investment resources (Peresada, 1998).

In conditions of economic and political risks, both internal and external, the key to improving the investment activities of enterprises in Ukraine is the consistent implementation of the steps declared by the new government:

- implementation of the judiciary and law enforcement agencies reform,

- implementation of systemic anti-corruption actions,

- ensuring transparency of public procurement,

- significant deregulation of the economy in accordance with European standards of doing business.

Exit from such crisis requires a purposeful state policy to socialize the market economy, increase of incomes of all the population segments to the level of supply of quality goods and services to provide a balance between market demand and supply of goods and services.

Overcoming the COVID-19 crisis by enterprises in Ukraine involves the following stages:

- stabilization (short-term) - the restoration of liquidity of banking institutions and enterprises of the real sector of the economy, prevention of their mass bankruptcy, stabilization of the state financial system and foreign economic relations with other countries;

- renewable (medium-term) - this stage implies the growth of domestic production of goods, primarily consumer goods, energy saving in all sectors of the economy; 
- qualitative growth (long-term) - improvement of the quality of public administration and building its integrated system, the development of high-tech sector of the economy based on accelerating the introduction of innovations.

Since the main directions of overcoming the crisis cannot be financed only from domestic sources, there is a need to attract loans. This is the most acute problem today. Therefore, it is very important to determine the optimal ratio and sequence of all actions of the crisis management mechanism of the business entity, necessary for a company in order to survive, not go bankrupt, which requires a protective strategy, and then to restore its solvency and start a new more effective stage of its activities in order to move to a development strategy. Among the methods of overcoming the consequences of the crisis in enterprises are the following: cost reduction; growth of the incoming funds; restructuring of accounts payable; reorganization or restructuring of the enterprise, improvement of its organizational structure and corporate governance, the formation of a portfolio of production technologies in accordance with the crisis of the market, the adjustment of sales policy and personnel management.

It is necessary to take priority measures to create the preconditions for economic growth: to increase domestic demand, to avoid reduction of state budget expenditures, to take measures to develop the domestic market, to intensify measures to regulate and limit unwanted imports, to create favourable conditions for foreign direct investment, to intensify export activities through the use of financial, legal, informational and diplomatic levers.

Important actions taken by government in order to overcome the crisis can be the partial nationalization of commercial banks while strengthening state control over their activities; mobilization of household savings and restoring confidence in the banking system; comprehensive assistance to small and medium-sized businesses; support for youth vocational training programs and expansion of retraining programs for unskilled workers; creation of new jobs due to the implementation of large-scale infrastructure projects by the state; elimination or significant restriction of tax benefits.

To overcome the economic crisis, it is necessary to develop effective public policy mechanisms aimed at providing market efficiency, ensuring compliance with legal norms, preventing unfair actions of business entities, especially monopolists, ensuring protection of property rights, creating conditions to combat raiding and reduce corruption by public authorities.

The first step is to achieve macroeconomic stability. It is clear that macroeconomic stability is a necessary condition for the development of scientifically sound systemic actions to combat the crisis, real planning of public finances and investment and manufacture programs and projects.

In this context, we should mention the bills aimed at solving the problems of the mining and metallurgical industry, construction, light industry and the agro-industrial sector.

In my opinion, further alignment of inter-sectoral and intra-industry price proportions, improvement of energy efficiency, search for domestic markets for products manufactured for export and by import substitution 
programs are required. Further prospects of innovation and investment activities of Ukrainian enterprises will be determined by the flexibility and efficiency of responding to changes of the competitive situation in the domestic market.

Analysis of the state's macroeconomic ambitions in terms of investment policy implementation shows that the declared tasks can be contradictory. Even a cursory review of government programs aimed at the development of the real sector of the economy will give grounds to conclude that there are many goals and objectives (achievement and implementation of which is possible only in an ideal model, free from external factors). The combination in one set of different regulatory measures leads to "scattering" of resources and loss of system control of the investment process (Gritsenko, 2011).

Stabilization of the economy and improvement of the innovation and investment climate require the adoption of a number of drastic measures aimed at forming in the country both general conditions of civilized market relations development and specific conditions, directly related to solving the problem of attracting investment. Such measures should primarily include:

- creation of the civilized non-criminal market and the mechanism of bankruptcy provided by the legislation at the national level;

- radicalization of the fight against crime;

- orientation of tax legislation towards stimulating production and investment;

- mobilization of free funds of enterprises and individuals for investment needs by raising interest rates on deposits and contributions;

- providing tax benefits to banks, domestic and foreign investors;

- creation of an investment climate monitoring system in Ukraine;

- creation of a system of support of foreign investments, which would combine a wide and competitive network of state institutions, commercial banks and insurance companies, protecting foreign capital from political and commercial risks; creation of the information intermediary centres engaged in the selection and ordering of projects relevant to Ukraine, the search for investors interested in their implementation and prompt execution of transactions (Yankovyi, Koval, Trokhymets, Karpenko, Matskevich, 2020).

To create an attractive investment climate and incentives for innovation, it is necessary to comprehensively involve state regulatory mechanisms, which are provided by budget, tax, monetary, depreciation and customs policy, improving the legal regulation in each of these areas. However, it is clear that solving a set of these tasks is possible only in the long run (Koval, Prymush, Popova, 2017).

\section{CONCLUSIONS}

Summarizing the above, investment attractiveness should be considered as an organized activity of enterprises that operate in the actual business conditions of the country with the help of investment entities; functions that consist in a purposeful process of finding the required amount of investment resources and selection of 
appropriate facilities or tools for their investment; development and implementation of a phased investment program or strategy and ensuring its effective implementation for profit.

An active state position and a comprehensive approach to solving existing problems related to the investment attractiveness of industrial enterprises in modern conditions will allow Ukraine to embrace its potential in the investment sphere with maximum efficiency. This will become a prerequisite for its sustainable economic development in the future.

Therefore, measures to intensify investment activities in enterprises should be carried out at all levels of management. It is necessary to try to create a favorable investment climate not only for foreign investors but also for Ukrainian ones. Fostering investment activities is possible through implementation of decisive, comprehensive, rapid, transparent and consistent market reforms, as well as through concerted management actions that will awaken entrepreneurial initiative, create a competitive environment and provide incentives for effective economic development.

The study revealed that the crisis is influenced by many factors, the most significant ones are disproportion of financial and industrial capital. Importers of negative trends in the Ukrainian economy have become domestic banks, which have significant debts to foreign partners. Now there are real opportunities to review priorities and discover new opportunities.

To overcome the crisis of enterprises and ensure the financial stability of industrial enterprises, solvency and profitability in the long run, it is necessary to implement and systematically improve financial management through the application of systems aimed at increasing cash flows while reducing costs, that will ultimately lead to improvement of financial state.

One of the main ways out of the recession for economy and to ensure further economic growth, in addition to eliminating the factors that caused the crisis, is finding new ways to create added value, create new goods and services that could better than existing ones meet new realities formed in the market as a result of changes in a number of factors.

Thus, as a result of the study, recommendations were developed to improve the investment attractiveness of the holding's industrial enterprises in the context of the COVID-19 pandemic.

These proposals are an important methodological basis for further study of the investment attractiveness of the holding's industrial enterprises in modern conditions.

\section{Conflict of interests}

The authors declare no conflict of interest.

\section{References}

Akhmetshin, E. M., Vasilev, V. L., Vlasova, N. I., Kazakov, A. V., Kotova, X. Y., \& Ilyasov, R. H. (2019). Improving management functions at an enterprise: Levels of the internal control system. Calitatea, 20(171), 39-43.

Babil, W. (2011). Analysis of the causes of the current financial crisis in Ukraine. Regional Economy, 1, 79. 
Baklanova, O., Petrova, M., Koval, V. (2020). Institutional Transmission in Economic Development. Ikonomicheski Izsledvania, 29(1), 68-91.

Blank, I. O. (ed) (2011). Financial support of enterprise development: monograph. Kiev.

Budnikova, Y.V. (2014) Investment attractiveness of the enterprise and factors influencing it. Innovative economy, 194197.

Cabinet of Ministers of Ukraine (2020). Annex to the State Program of Economic Incentives to Overcome the Negative Consequences of Restrictive Measures to Prevent the Occurrence and Spread of Coronavirus Disease (COVID-19) for 2020-2022. Retrieved from: https://www.kmu.gov.ua

Endovitsky, D. A. (2010). Analysis of investment attractiveness of the organization. KnoRus Publishing House.

Gritsenko, V. (2011). The global financial crisis: diagnostics and new approaches to survival in the financial market. Bulletin of the NBU, 2, 1- 2 .

Gura, O. (2018). Start-up as a tool for implementation of investment decisions. Economics. Ecology. Socium, 2(2), 1-11.

Khidirov, N. (2020). Specific features of financing investment activity of industrial enterprises. International Finance and Accounting, (1), 31.

Koval, V., Prymush, Y., Popova, V. (2017). The influence of the enterprise life cycle on the efficiency of investment. Baltic Journal of Economic Studies, 3(5), 183-187. https://doi.org/10.30525/2256-0742/2017-3-5-183-187

Labunska Sv., Petrova M., Prokopishyna O. (2017). Asset and cost management for innovation activity, "Economic Annals - XXI", Volume 165, Issue 5-6, 2017, Pages: 13-18. DOI: https://doi.org/10.21003/ea.V165-03

Madaminjonov, O. R. (2020). The importance of a favorable investment climate for the consistent implementation of structural changes in the regional economy. South Asian Journal of Marketing \& Management Research, 10(4), 6069.

Matyushenko, I., Hlibko, S., Petrova, M. M., Pasmor, M. S., \& Loktionova, M. (2020). Assessment of the development of foreign trade in high-tech production of Ukraine under the association with the EU. Business, Management and Education, 18(1), 157-182. https://doi.org/10.3846/bme.2020.11578

Peresada, A. A. (1998). Investment process in Ukraine, Kyiv.

Petrova, M., Koval, V., Tepavicharova, M., Zerkal, A., Radchenko, A., \& Bondarchuk, N. (2020). The interaction between the human resources motivation and the commitment to the organization. Journal of Security \& Sustainability Issues, 9(3): 897-907. https://doi.org/10.9770/jssi.2020.9.3(15)

Petrovich, J.M. (2008). Organizational and economic principles of accelerating innovation processes in the industry of Ukraine. Bulletin of the National University "Lviv Polytechnic". Series: Problems of Economics and Management, $628,3-11$.

Ramazanov, S. Petrova, M. (2020). Development management and forecasting in a green innovative economy based on the integral dynamics model in the conditions of «Industry - 4.0». Access journal, ACCESS Press, 1(1): 9-30, DOI: https://doi.org/10.46656/access.2020.1.1(1).

Seitzhanov, S., Kurmanov, N., Petrova, M., Aliyev, U., Aidargaliyeva, N. 2020. Stimulation of entrepreneurs' innovative activity: evidence from Kazakhstan. Entrepreneurship and Sustainability Issues, 7(4), 2615-2629. https://doi.org/10.9770/jesi.2020.7.4(4)

Sushchenko, O. (2016). Creation of innovation clusters as a line of enterprise competitiveness improvement in the field of foreign economic activity, Actual Problems of Economics, 177(3), 191-198

Sushchenko, O., Trunina, I., Klok, O., Loseva, O. (2019). Management technologies of ensuring environmental protection as the territory development strategic priority //(IES2018) SHS Web Conference. Volume 61. https://doi.org/10.1051/shsconf/20196101026

Tepavicharova, M., Aleksejeva, L., Vazov, R. (2020). Interaction of Subordinate Staff Management and Factors of Economic Performance of Companies in the Bulgarian Mining and Quarrying Sector. Vth International Innovative Mining Symposium, E3S Web of Conf. 174, 04031, https://doi.org/10.1051/e3sconf/202017404031

Usherenko, S. (2010). Directions of formation of effective management of Ukrainian enterprises in the post-crisis period. Formation of market relations in Ukraine, 10, 54.

Vorobiev, Y. N., Vorobieva, E. I. (2004). Investing: textbook. Kiev. 
Yankovyi O., Koval V., Trokhymets O., Karpenko M., Matskevich Y. (2020). Economic assessment of investment on the basis of production functions. Turismo: Estudos \&Práticas, 2.

Zagorodnya, A., Dichek, N., Chobitko, N., Voznyk, M., Honchar, L., Petrova, M. (2020). Professional training of the economic sector specialists at higher education institutions of the Republic of Poland and Ukraine: criteria of comparison. International Journal of Higher Education, Vol. 9, No. 3, June 2020, pp.139-144, https://doi.org/10.5430/ijhe.v9n3p139

Zhernov, E., Nekhoda, E., \& Petrova, M. (2020). Economic Transformation Impact on the Modernization of a Mineral Resource Industry Cluster. In E3S Web of Conferences (Volume 174, p. 04003). EDP Sciences. https://doi.org/10.1051/e3sconf/202017404003

\section{About the author:}

Olena OCHEREDCO, Senior Lecturer, Department of Management and Entrepreneurship on Sea Transport, Azov Maritime Institute of National University «Odessa Maritime Academy». Research interests: management, project and services, business administration, investment, sustainable development.

ORCID ID: https://orcid.org/0000-0002-3438-0633

Copyright (C) 2020 by author(s) and ACCESS Publishing Press This work is licensed under the Creative Commons Attribution International License (CC BY) 